\title{
Diagnosis Penyakit Tanaman Karet dengan Metode Fuzzy Mamdani
}

\author{
Hendrawan ${ }^{1}$, Abdul Haris ${ }^{2}$, Errissya Rasywir ${ }^{3}$, Yovi Pratama ${ }^{4}$ \\ ${ }^{1,2,3,4}$ Universitas Dinamika Bangsa Jambi \\ e-mail: ${ }^{1}$ hendrawan.stikom@gmail.com, ${ }^{2}$ abdulharris@ stikom-db.ac.id, ${ }^{3}$ errissya.rasywir@gmail.com, \\ ${ }^{4}$ yovi.pratama@gmail.com
}

\begin{abstract}
Like most plantation plants in general, rubber can be attacked by various diseases originating from fungi, pests, animals and even cancer cells. For that we need a method capable of diagnosing rubber disease. In previous research related to the diagnosis of plant diseases, among others, using the Dempster Shafer method, the Certainty factor method and forward chaining. This study developed an analysis of the results of the diagnosis of rubber plant disease using the Mamdany Fuzzy method. The choice of this method departs from research on fuzzy mamdany which states that the fuzzy mamdany method is able to resemble the intuitive way the human brain works. It is hoped that with this method, the diagnosis of rubber plant disease can help farmers detect symptoms earlier so that the productivity of rubber plantation products can be achieved. increased. This study used rubber plant disease data from the Jambi Provincial Plantation Office in Jambi City. From the results of calculations carried out in diagnosing rubber plant disease, as many as 161 rubber plant object data were equipped with 33 symptom identities and a diagnosis from plantation data, then tested 60 rubber plant data without a diagnostic label, we obtained an accuracy value of $81.28 \%$. Likewise, testing by randomizing training data with Cross Validation obtained close results.
\end{abstract}

Keywords: Fuzzy, Mamdani, Evaluation, Diagnosis.

\begin{abstract}
Abstrak - Seperti kebanyakan tanaman perkebunan pada umumnya, karet dapat terserang berbagai penyakit yang bersumber dari jamur, hama, hewan bahkan sel kanker. Untuk itu diperlukan suatu metode yang mampu mendiagnosis penyakit karet. Pada penelitian sebelumnya terkait dengan diagnosa penyakit tanaman antara lain menggunakan metode Dempster Shafer, metode faktor kepastian dan forward chaining. Penelitian ini mengembangkan analisis hasil diagnosis penyakit tanaman karet dengan menggunakan metode Mamdany Fuzzy. Pemilihan metode ini berangkat dari penelitian fuzzy mamdany yang menyatakan bahwa metode fuzzy mamdany mampu menyerupai cara kerja otak manusia secara intuitif. Dengan metode ini diharapkan diagnosis penyakit tanaman karet dapat membantu petani dalam mendeteksi gejala lebih dini sehingga produktivitas hasil perkebunan karet dapat tercapai. meningkat. Penelitian ini menggunakan data penyakit tanaman karet dari Dinas Perkebunan Provinsi Jambi Kota Jambi. Dari hasil perhitungan yang dilakukan dalam mendiagnosis penyakit tanaman karet, sebanyak 161 data objek tanaman karet dilengkapi dengan 33 identitas gejala dan diagnosa dari data perkebunan, kemudian dilakukan pengujian 60 data tanaman karet tanpa label diagnostik, diperoleh nilai akurasi. dari 81,28\%. Begitu pula dengan pengujian dengan mengacak data latih dengan Cross Validation memperoleh hasil yang mendekati.
\end{abstract}

Kata Kunci: Fuzzy, Mamdani, Evaluasi, Diagnosis.

\section{PENDAHULUAN}

Banyak produk menggunakan bahan baku karet seperti ban kendaraan, alat rumah tangga, produk tas dan sepatu dari karet sintetis, bantalan karet pelindung serta mainan anak. Selain itu, pohon karet mempunyai kelebihan yakni mampu menyerap gas buangan dan menghasilkan jumlah oksigen yang jauh lebih maksimal dibanding tumbuhan lainnya (Filie \& Kusuma, 2011). Saat ini, produksi karet menjadi andalan komoditas di provinsi Jambi. Perlu dilakukan upaya peningkatan produksi dari getah karet sebagai produk unggulan penggerak ekonomi provinsi Jambi. Seperti kebanyakan tumbuhan perkebunan, karet dapat diserang berbagai penyakit yang berasal dari jamur, hama, binatang bahkan sel kanker (Maulana, Rizky, Fitriyadi, \& Fitriani, 2017). Penyakit-penyakit tersebut dapat menyebabkan kerugian dalam industri perkebunan karet (Maulana et al., 2017). Namun, keterbatasan pengetahuan petani karet mengenai gejala yang ditimbulkan pada penyakit tumbuhan karet dapat menyebabkan produksi getah karet menurun (Nurhatika, 2013).

Karet (Hevea Brasiliensis) merupakan tumbuhan industri dengan bentuk pohon batang yang lurus dan mulai dibudidayakan pada tahun 1601 (Mustaqim, 2013). Getah karet dihasilkan oleh pohon karet ini berwarna putih dan berbentuk cairan (Fajri, 2014; Maulana et al., 2017). Cara pengambilan getah karet adalah dengan cara disadap. Banyak produk yang menggunakan bahan baku karet seperti ban kendaraan, alat-alat rumah tangga, produk fashion seperti tas dan sepatu dari karet sintetis, bantalan karet pelindung serta mainan anak (Maulana et al., 2017; Nurhatika, 2013). Selain itu, pohon karet http://ejournal.bsi.ac.id/ejurnal/index.php/paradigma/issue/archive/ 
mempunyai kelebihan yakni mampu menyerap gas buangan dan menghasilkan jumlah oksigen yang jauh lebih maksimal dibanding tumbuhan lainnya (Nurhatika, 2013; Sidauruk \& Pujianto, 2017). Sampai saat ini produksi karet masih menjadi andalan komoditas di provinsi Jambi. Sehingga, perlu dilakukan upaya peningkatan produksi dari getah karet sebagai produk unggulan penggerak ekonomi provinsi Jambi.

Seorang ahli perkebunan mampu mendiagnosis jenis penyakit tumbuhan karet, namun dibutuhkan effort untuk menggunakan jasa seorang pakar pertanian dalam melakukan diagnosis gejala penyakit karet. Untuk itu dibutuhkan sebuah sistem yang mampu menggantikan keahlian seorang pakar pertanian dalam melakukan diagnosis penyakit karet.

Penelitian sebelumnya yang melakukan diagnosis penyakit tumbuhan antara lain menggunakan metode Dempster Shafer, metode Certainty factor maupun forward chaining (Hayadi \& Setiawan, 2016; Kamsyakawuni, Gernowo, \& Sarwoko, 2012). Namun, penelitian yang mengembangkan metode diagnosis penyakit tumbuhan masih sangat sedikit jumlahnya. Sehingga, perlu dilakukan penelitian lebih lanjut mengenai diagnosis penyakit tumbuhan karet dengan berbagai metode lainnya.

Di indonesia perkembangan tumbuhan karet sangat pesat mengingat indonesia merupakan negara agraris dan telah menjadi sektor ekonomi utama. Namun, tumbuhan karet dapat diserang penyakit sehingga menyebabkan kerugian Berikut ini adalah beberapa contoh gambar dari penyakit pada tumbuhan karet.

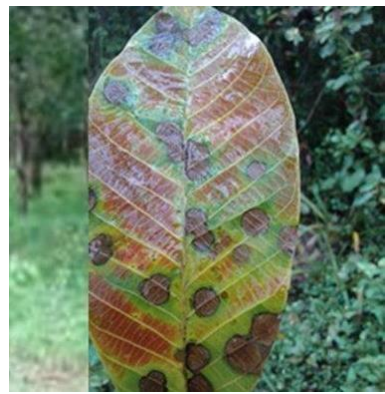

Gambar 1. Penyakit Gugur Daun Pada Tumbuhan Karet (Maulana et al., 2017)

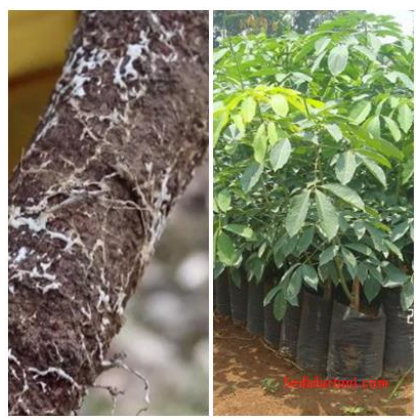

Gambar 2. Penyakit Akar Putih Pada Tumbuhan Karetc
Dalam penelitian ini, digunakan metode Mamdany Fuzzy. Pemilihan metode tersebut berangkat dari penelitian mengenai mamdany fuzzy yang menyatakan bahwa metode mamdany fuzzy mampu menyerupai cara kerja otak manusia (Kaur \& Kaur, 2012; Sumitre, Kurniawan, Informatika, \& Alam, 2014) yang bersifat intuitif. Penelitian ini menggunakan data penyakit tumbuhan karet dari Dinas Perkebunan provinsi Jambi yang terletak di Kota Jambi. Data penyakit tumbuhan karet disimpan sebagai knowledge dan experience yang dihasilkan metode mamdany fuzzy dan digunakan untuk proses pengujian diagnosis penyakit tumbuhan karet.

\section{METODOLOGI PENELITIAN}

Pada bagian metodologi ini, kami sajikan langkah dan alur kegiatan penelitian ini. Berikut ini adalah langkah penelitian yang kami lakukan.

\section{a. Analisis Permasalahan Diagnosis Penyakit Tumbuhan Karet.}

Seperti kebanyakan tumbuhan perkebunan, karet dapat diserang berbagai penyakit yang berasal dari jamur, hama, binatang bahkan sel kanker (Maulana et al., 2017). Penyakit-penyakit tersebut dapat menyebabkan kerugian dalam industri perkebunan karet. Namun, keterbatasan pengetahuan petani karet mengenai gejala yang ditimbulkan pada penyakit tumbuhan karet dapat menyebabkan produksi getah karet menurun (Maulana et al., 2017). Seorang ahli atau pakar pertanian dan perkebunan mampu mendiagnosis jenis penyakit tumbuhan karet. Tapi membutuhkan effort yang lebih untuk menggunakan jasa seorang pakar pertanian dalam melakukan diagnosis gejala penyakit disetiap kegiatan produksi getah karet.

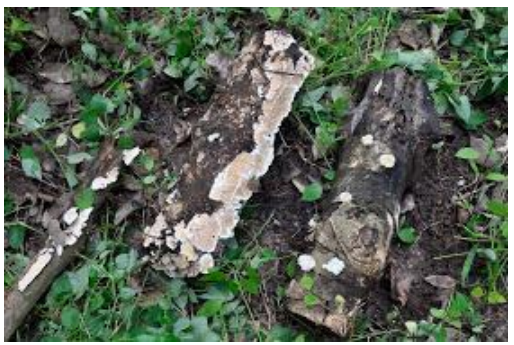

Gambar .3 Penyakit Jamur Akar Putih Pada Tumbuhan Karet

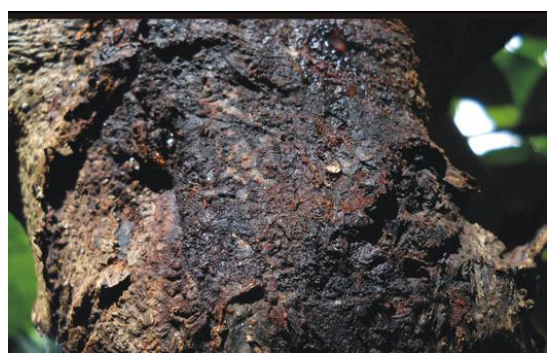




\section{Gambar 4. Penyakit Kanker Kulit Pada Tumbuhan} Karet

\section{b. Analisis Penerapan Metode Fuzzy Mamdani.}

Metode Mamdani ditemukan oleh Ebrahim Mamdani pada tahun 1975. Mamdany Fuzzy ini merupakan metode yang paling populer digunakan dalam aplikasi fuzzy (Mahua, 2018). Metode ini menggunakan output yang ditentukan menggunakan metode MIN yang aturannya diinterferensikan menggunakan metode MAX (Kamsyakawuni et al., 2012; Kaur \& Kaur, 2012). Sehingga metode Mamdani juga dikenal dengan metode MIN-MAX.

Namun, metode Mamdani bukan hanya proses pembatasan nilai MIN-MAX. Metode mamdany juga menggunakan metode penjumlahan (sum) untuk memperoleh solusi himpunan fuzzy terhadap semua output daerah fuzzy. Selain itu, Metode mamdany fuzzu menggunakan metode probabilistik OR untuk memperoleh solusi himpunan fuzzy dengan cara melakukan perkalian pada semua output daerah fuzzy(Sumitre et al., 2014).

Dalam penelitian ini, digunakan metode Mamdany Fuzzy. Pemilihan metode tersebut berangkat dari penelitian mengenai mamdany fuzzy yang menyatakan bahwa metode mamdany fuzzy mampu menyerupai cara kerja otak manusia yang bersifat intuitif.

\section{c. Implementasi pada Diagnosis Penyakit Tumbuhan Karet}

Pada tahap ini, kami menerapkan proses perhitungan algoritma Fuzzy Mamdani pada data tanaman karet yang telah kami peroleh sebanyak 191 data penyakit tanaman Karet.

Tabel 1. Gejala atau Sympton Penciri Penyakit Pada Tanaman Karet.

\begin{tabular}{|c|c|}
\hline Kode & Parameter \\
\hline $\mathrm{P} 1$ & Warna pada daun menjadi hijau kusam dan kaku \\
\hline $\mathrm{P} 2$ & $\begin{array}{l}\text { Terdapat jamur berwarna putih menyelimuti } \\
\text { permukaan akar }\end{array}$ \\
\hline P3 & Akar tanaman membusuk \\
\hline & Badan buah berwarna orange dengan tepi berwarna \\
\hline P4 & kuning muda atau keputihan. \\
\hline P5 & $\begin{array}{l}\text { Terdapat bercak berwarna putih seperti tepung di } \\
\text { permukaan bawah daun }\end{array}$ \\
\hline P6 & Daun berwarna hitam \\
\hline P7 & Terdapat bercak transparan pada daun tua \\
\hline P8 & Daun mati dan akhirnya gugur \\
\hline P9 & Daun terlihat lemas \\
\hline $\mathrm{P} 10$ & Bercak hitam pada tulang daun \\
\hline $\mathrm{P} 11$ & Daun menguning atau kecoklatan \\
\hline $\mathrm{P} 12$ & Daun mengering dan berlubang \\
\hline P13 & Kulit batang menjadi membusuk \\
\hline P14 & Permukaan kulit batang pecah-pecah \\
\hline $\mathrm{P} 15$ & Adanya bercak coklat kehitaman pada batang \\
\hline P16 & Adanya bercak basah \\
\hline P17 & $\begin{array}{l}\text { Terdapat sebara seperti sarang laba-laba melekat } \\
\text { pada permukaan daun }\end{array}$ \\
\hline P18 & $\begin{array}{l}\text { Kulit yang terserang terdapat selaput (mielia jamur) } \\
\text { tebal }\end{array}$ \\
\hline P19 & Cabang atau ranting yang terserang mati \\
\hline $\mathrm{P} 20$ & Adanya bercak-bercak hitam pada bidang sadap \\
\hline
\end{tabular}

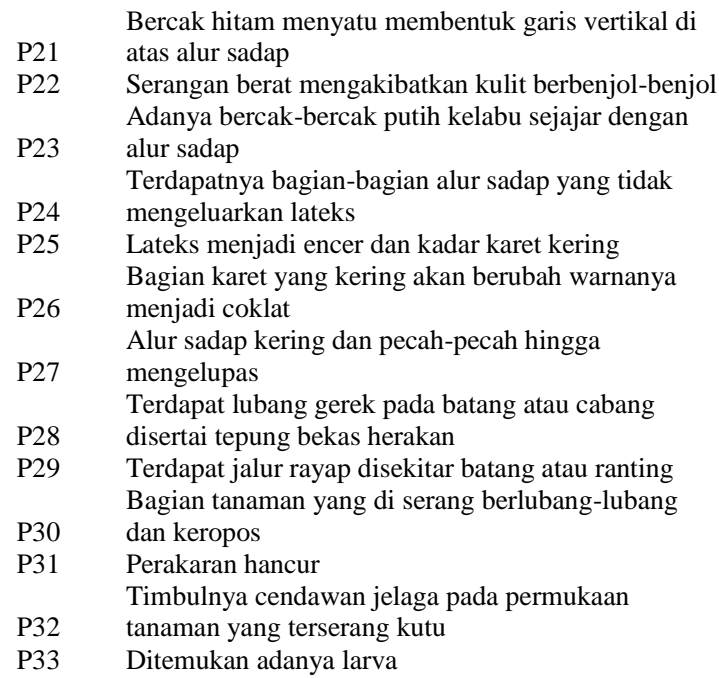

\section{d. Analisis Pengujian Diagnosis Penyakit Tumbuhan Karet Metode Fuzzy Mamdani.}

Pada bagian ini, kami melakukan pengujian terhadap penerapan algoritma Fuzzy Mamdani uuntuk diagnosis tanaman karet.

Evaluasi pengujian disimpan menggunakan akurasi di mana nilai akurasi adalah hasil perbandingan diagnosis pakar manusia dibanding dengan diagnosis metode. Tujuan dari penelitian ini diharapkan diagnosis penyakit tumbuhan karet dapat dilakukan secara otomatis untuk membantu perekonomian hasil kebun petani di Jambi, kemudian mengetahui evaluasi hasil diagnosis pakar manusia dibanding dengan diagnosis dengan metode, serta mengetahui hasil penerapan metode Mamdany Fuzzy pada penyakit tumbuhan karet. Untuk mencapai tujuan tersebut kami melakukan analisis hasil Diagnosis Penyakit Tumbuhan Karet dengan Metode Fuzzy Mamdani.

\section{HASIL DAN PEMBAHASAN}

Pada bagian ini, kami menjelaskan hasil penerapan algoritma Fuzzy Mamdani pada pekerjaan diagnosis penyakit pada tanaman karet berdasarkan gejala yang telah kami daftarkan di tabel 1 .

\section{Hasil Pembentukan Himpunan Fuzzy}

Tabel 2. Pembentukan Semesta Dan Unit Dari Setiap Gejala Pada Penyakit Tanaman Karet

\begin{tabular}{clcl}
\hline Variabel & Himpunan & Semesta & Unit \\
\hline \multirow{2}{*}{$\begin{array}{c}\text { Harna pada daun menjadi } \\
\text { hijau kusam dan kaku }\end{array}$} & Sedikit & $0-25$ & $0-5$ \\
Kusam & & $10-15$ \\
\hline $\begin{array}{c}\text { Terdapat jamur berwarna } \\
\text { putih menyelimuti }\end{array}$ & Tidak Ada & & $0-40$ \\
permukaan akar & Sedikit & $0-70$ & $20-60$ \\
& Putih & & $40-70$ \\
\hline Tidak Ada & & $0-40$ \\
Akar tanaman membusuk & Sedikit & $0-70$ & $20-60$ \\
\hline Badan buah berwarna orange & Tidak Ada & $0-25$ & $0-5$
\end{tabular}


Paradigma - Jurnal Informatika dan Komputer,

Vol. 22, No. 2 September 2020

P-ISSN 1410-5063, E-ISSN: 2579-3500

\begin{tabular}{|c|c|c|c|}
\hline \multirow{4}{*}{$\begin{array}{c}\text { dengan tepi berwarna kuning } \\
\text { muda atau keputihan. } \\
\text { Terdapat bercak berwarna } \\
\text { putih seperti tepung di } \\
\text { permukaan bawah daun }\end{array}$} & \multicolumn{2}{|l|}{$\begin{array}{l}\text { Sedikit } \\
\text { Orange }\end{array}$} & $\begin{array}{l}5--15 \\
10--25\end{array}$ \\
\hline & Hijau & & $0-30$ \\
\hline & Sedikit & $0-60$ & $10--50$ \\
\hline & Putih & & $30-60$ \\
\hline \multirow[b]{3}{*}{ Daun berwarna hitam } & Hijau & \multirow{3}{*}{$0-60$} & $0-30$ \\
\hline & Sedikit & & $10--50$ \\
\hline & Hitam & & $30-60$ \\
\hline \multirow{3}{*}{$\begin{array}{l}\text { Terdapat bercak transparan } \\
\text { pada daun tua }\end{array}$} & Tidak Ada & \multirow{3}{*}{$0-70$} & $0-40$ \\
\hline & Sedikit & & $20-60$ \\
\hline & Jelas & & $40-70$ \\
\hline \multirow{3}{*}{$\begin{array}{l}\text { Daun mati dan akhirnya } \\
\text { gugur }\end{array}$} & Tidak Ada & \multirow{3}{*}{$0-70$} & $0-40$ \\
\hline & Sedikit & & $20-60$ \\
\hline & Jelas & & $40-70$ \\
\hline \multirow[b]{3}{*}{ Daun terlihat lemas } & Kencang & \multirow{3}{*}{$0-60$} & $0-30$ \\
\hline & Layu & & $10--50$ \\
\hline & Lemas & & $30-60$ \\
\hline & Tidak Ada & & $0-30$ \\
\hline Bercak hitam pada tulang & Sedikit & $0-60$ & $10--50$ \\
\hline daun & Hitam & & $30-60$ \\
\hline & Hijau & & $0-30$ \\
\hline Daun menguning atau & Coklat & $0-60$ & $10--50$ \\
\hline kecoklatan & Kuning & & $30-60$ \\
\hline & Tidak Ada & & $0-40$ \\
\hline Daun mengering dan & Sedikit & $0-70$ & $20-60$ \\
\hline berlubang & Jelas & & $40-70$ \\
\hline & Tidak Ada & & $0-40$ \\
\hline Kulit batang menjadi & Sedikit & $0-70$ & $20-60$ \\
\hline membusuk & Jelas & & $40-70$ \\
\hline & Mulus & & $0-30$ \\
\hline Permukaan kulit batang & Sedikit & $0-60$ & $10--50$ \\
\hline pecah-pecah & Pecah & & $30-60$ \\
\hline & Hijau & & $0-30$ \\
\hline Adanya bercak coklat & Sedikit & $0-60$ & $10--50$ \\
\hline kehitaman pada batang & Hitam & & $30-60$ \\
\hline & Segar & & $0-30$ \\
\hline & Sedikit & $0-60$ & $10--50$ \\
\hline Adanya bercak basah & Basah & & $30-60$ \\
\hline Terdapat sebara seperti & Tidak Ada & & $0-40$ \\
\hline sarang laba-laba melekat & Sedikit & $0-70$ & $20-60$ \\
\hline pada permukaan daun & Jelas & & $40-70$ \\
\hline & Tidak Ada & & $0-40$ \\
\hline Kulit yang terserang terdapat & Sedikit & $0-70$ & $20-60$ \\
\hline selaput (mielia jamur) tebal & Jelas & & $40-70$ \\
\hline & Tidak Ada & & $0-40$ \\
\hline Cabang atau ranting yang & Sedikit & $0-70$ & $20-60$ \\
\hline terserang mati & Jelas & & $40-70$ \\
\hline & Tidak Ada & & $0-40$ \\
\hline Adanya bercak-bercak hitam & Sedikit & $0-70$ & $20-60$ \\
\hline pada bidang sadap & Jelas & & $40-70$ \\
\hline Bercak hitam menyatu & Tidak Ada & & $0-40$ \\
\hline membentuk garis vertikal di & Sedikit & $0-70$ & $20-60$ \\
\hline atas alur sadap & Jelas & & $40-70$ \\
\hline Serangan berat & Tidak Ada & & $0-40$ \\
\hline mengakibatkan kulit & Sedikit & $0-70$ & $20-60$ \\
\hline berbenjol-benjol & Jelas & & $40-70$ \\
\hline Adanya bercak-bercak putih & Tidak Ada & & $0-40$ \\
\hline kelabu sejajar dengan alur & Sedikit & $0-70$ & $20-60$ \\
\hline sadap & Jelas & & $40-70$ \\
\hline Terdapatnya bagian-bagian & Tidak Ada & & $0-40$ \\
\hline alur sadap yang tidak & Sedikit & $0-70$ & $20-60$ \\
\hline mengeluarkan lateks & Jelas & & $40-70$ \\
\hline & Tidak Ada & & $0-40$ \\
\hline Lateks menjadi encer dan & Sedikit & $0-70$ & $20-60$ \\
\hline kadar karet kering & Jelas & & $40-70$ \\
\hline Bagian karet yang kering & Tidak Ada & & $0-40$ \\
\hline akan berubah warnanya & Sedikit & $0-70$ & $20-60$ \\
\hline menjadi coklat & Jelas & & $40-70$ \\
\hline Alur sadap kering dan & Tidak Ada & & $0-40$ \\
\hline pecah-pecah hingga & Sedikit & $0-70$ & $20-60$ \\
\hline mengelupas & Jelas & & $40-70$ \\
\hline Terdapat lubang gerek pada & Tidak Ada & & $0-40$ \\
\hline batang atau cabang disertai & Sedikit & $0-70$ & $20-60$ \\
\hline tepung bekas herakan & Jelas & & $40-70$ \\
\hline
\end{tabular}

\begin{tabular}{|c|c|c|c|}
\hline $\begin{array}{c}\text { Terdapat jalur rayap } \\
\text { disekitar batang atau ranting }\end{array}$ & $\begin{array}{l}\text { Tidak Ada } \\
\text { Sedikit } \\
\text { Jelas }\end{array}$ & $0-70$ & $\begin{array}{l}0-40 \\
20-60 \\
40-70\end{array}$ \\
\hline $\begin{array}{l}\text { Bagian tanaman yang di } \\
\text { serang berlubang-lubang dan } \\
\text { keropos }\end{array}$ & $\begin{array}{l}\text { Utuh } \\
\text { Sedikit } \\
\text { Berlubang }\end{array}$ & $0-80$ & $\begin{array}{l}0-40 \\
10--70 \\
40-80\end{array}$ \\
\hline Perakaran hancur & $\begin{array}{l}\text { Utuh } \\
\text { Sedikit } \\
\text { Hancur }\end{array}$ & $0-70$ & $\begin{array}{l}0-40 \\
20-60 \\
40-70\end{array}$ \\
\hline $\begin{array}{c}\text { Timbulnya cendawan jelaga } \\
\text { pada permukaan tanaman } \\
\text { yang terserang kutu }\end{array}$ & $\begin{array}{l}\text { Tidak Ada } \\
\text { Sedikit } \\
\text { Jelas }\end{array}$ & $0-70$ & $\begin{array}{l}0-40 \\
20-60 \\
40-70\end{array}$ \\
\hline Ditemukan adanya larva & $\begin{array}{l}\text { Tidak Ada } \\
\text { Sedikit } \\
\text { Jelas }\end{array}$ & $0-70$ & $\begin{array}{l}0-40 \\
20-60 \\
40-70\end{array}$ \\
\hline
\end{tabular}

Nilai pada tabel 2 digunakan untuk melakukan perhitungan dengan algoritma fuzzy untuk tanaman karet. Setiap variabel gejala penyakit pada tanaman karet, terdapat beberapa variabel lagi yang menyatakan tingkatan dari gejala yang dialami oleh tanaman karet. Kemudian, setiap tingkatan nilai keparahan gejala, kami berikan rentang nilai.

Tabel 3. Pengkondisian Rentang Semesta pada Gejala Penyakit Tanaman Karet (Rentang 0-25 dan 0-60).

\begin{tabular}{|c|c|}
\hline Rentang Semesta 0-25 & Rentang Semesta 0-60 \\
\hline$\mu$ Rendah [Gejala] & $\mu$ Rendah [Gejala] \\
$\{1$, untuk $x \leq 5$ & $\{1$, untuk $x \leq 10$ \\
$\frac{5-\mathrm{x}}{5-10}$, untuk $0 \leq x \geq 10$ & $\frac{30-\mathrm{x}}{30-10}$, untuk $10 \leq x \geq 30$ \\
0 , untuk $x \geq 5$ & 0 , untuk $x \geq 30$ \\
$\mu$ Sedang [Gejala] & $\mu$ Sedang [Gejala] \\
$\{0$, untuk $x \leq 10$, & $\{0$, untuk $x \leq 50$, \\
$\frac{\mathrm{x}-5}{10-5}$, untuk $5 \leq x \leq 10$ & $\frac{\mathrm{x}-10}{20-10}$, untuk $10 \leq x \leq 30$ \\
$\frac{15-\mathrm{x}}{15-5}$, untuk $10 \leq x \leq 15$ & $\frac{50-\mathrm{x}}{50-30}$, untuk $30 \leq x \leq 50$ \\
0, untuk $x \leq 15$, & 0, untuk $x \leq 30$, \\
$\mu$ Tinggi $[$ Gejala] & $\mu$ Tinggi $[$ Gejala] \\
$\{0$, untuk $x \leq 15$ & $\{0$, untuk $x \leq 30$ \\
$\frac{\mathrm{x}-10}{15-10}$, untuk $15 \leq x \leq 25$ & $\frac{\mathrm{x}-30}{50-30}$, untuk $500 \leq x \leq 750$ \\
1, untuk $\geq 25$ & 1, untuk $\geq 50$ \\
\hline
\end{tabular}

Tabel 3 di atas, ditampilkan kondisi rentang semesta pada gejala penyakit tanaman karet dengan nilai rentang 0-25 dan 0-60. Terdapat beberapa instruksi yang dijalankan dalam algoritma fuzzy mamdani, jika kondisi tersebut dapat terpenuhi.

Tabel 4. Pengkondisian Rentang Semesta pada Gejala

Penyakit Tanaman Karet (Rentang 0-70 dan 0-80).

\begin{tabular}{|l|l|}
\hline Rentang Semesta 0-70 & Rentang Semesta 0-80 \\
\hline$\mu$ Rendah [Gejala] & $\mu$ Rendah [Gejala] \\
$\{1$, untuk $x \leq 20$ & $\{1$, untuk $x \leq 10$ \\
$\frac{40-\mathrm{x}}{40-20}$, untuk $20 \leq x \geq 40$ & $\frac{40-\mathrm{x}}{40-20}$, untuk $10 \leq x \geq 40$ \\
0, untuk $x \geq 40$ & 0, untuk $x \geq 40$ \\
$\mu$ Sedang [Gejala] $\quad$ & $\mu$ Sedang [Gejala] \\
$\{0, \quad$ untuk $x \quad 40$, & $\{0$, untuk $x \leq 40$ atau $x \geq 70$, \\
$\frac{x-20}{40-20}$, untuk $20 \leq x \leq 40$ & $\frac{x-10}{40-10}$, untuk $20 \leq x \leq 40$ \\
$\frac{60-\mathrm{x}}{60-40}$, untuk $40 \leq x \leq 60$ & $\frac{70-\mathrm{x}}{70-40}$, untuk $40 \leq x \leq 70$ \\
0, untuk $x \leq 40$, & 0, untuk $x \leq 40$, \\
$\mu$ Tinggi $[$ Gejala] & $\mu$ Tinggi $[$ Gejala] \\
$\{0$, untuk $x \leq 30$ & $\{0$, untuk $x \leq 30$ \\
$\frac{x-60}{60-40}$, untuk $40 \leq x \leq 60$ & $\frac{x-40}{70-40}$, untuk $40 \leq x \leq 70$ \\
1, untuk $\geq 60$ & 1, untuk $\geq 70$ \\
\hline
\end{tabular}

Tabel 4 di atas, ditampilkan kondisi rentang semesta pada gejala penyakit tanaman karet dengan nilai 
rentang 0-70 dan 0-80. Terdapat beberapa instruksi seperti $1, \frac{40-x}{40-20}, 0, \frac{x-20}{40-20}$ dan $\frac{60-x}{60-40}$ yang dijalankan dalam algoritma fuzzy mamdani, jika kondisi tersebut dapat terpenuhi.

Tabel 5. Daftar Kode Variabel dan Kode Kelas dari Rentang dari Rendah ke Tinggi.

\begin{tabular}{|c|c|c|c|}
\hline $\begin{array}{l}\text { Kode } \\
\text { Variabel }\end{array}$ & $\begin{array}{l}\text { Kode } \\
\text { (Rendah) }\end{array}$ & $\begin{array}{l}\text { Kode } \\
\text { (Sedang) }\end{array}$ & $\begin{array}{l}\text { Kode } \\
\text { (Tinggi) }\end{array}$ \\
\hline P1 & P1R & P1S & P1T \\
\hline P2 & $\mathrm{P} 2 \mathrm{R}$ & $\mathrm{P} 2 \mathrm{~S}$ & $\mathrm{P} 2 \mathrm{~T}$ \\
\hline P3 & P3R & P3S & P3T \\
\hline P4 & P4R & $\mathrm{P} 4 \mathrm{~S}$ & P4T \\
\hline P5 & P5R & P5S & P5T \\
\hline P6 & P6R & P6S & P6T \\
\hline P7 & P7R & P7S & P7T \\
\hline P8 & P8R & P8S & P8T \\
\hline P9 & P9R & P9S & P9T \\
\hline P10 & P10R & P10S & P10T \\
\hline P11 & P11R & P11S & $\mathrm{P} 11 \mathrm{~T}$ \\
\hline P12 & P12R & P12S & $\mathrm{P} 12 \mathrm{~T}$ \\
\hline P13 & P13R & P13S & $\mathrm{P} 13 \mathrm{~T}$ \\
\hline P14 & P14R & P14S & $\mathrm{P} 14 \mathrm{~T}$ \\
\hline P15 & P15R & P15S & $\mathrm{P} 15 \mathrm{~T}$ \\
\hline P16 & P16R & P16S & P16T \\
\hline P17 & P17R & P17S & P17T \\
\hline P18 & P18R & P18S & P18T \\
\hline P19 & P19R & P19S & $\mathrm{P} 19 \mathrm{~T}$ \\
\hline P20 & P20R & P20S & P20T \\
\hline P21 & P21R & P21S & P21T \\
\hline P22 & P22R & $\mathrm{P} 22 \mathrm{~S}$ & $\mathrm{P} 22 \mathrm{~T}$ \\
\hline P23 & P23R & $\mathrm{P} 23 \mathrm{~S}$ & $\mathrm{P} 23 \mathrm{~T}$ \\
\hline P24 & P24R & $\mathrm{P} 24 \mathrm{~S}$ & $\mathrm{P} 24 \mathrm{~T}$ \\
\hline P25 & P25R & P25S & P25T \\
\hline P26 & P26R & P26S & P26T \\
\hline P27 & P27R & P27S & P27T \\
\hline P28 & P28R & P28S & P28T \\
\hline P29 & P29R & P29S & P29T \\
\hline P30 & P30R & P30S & P30T \\
\hline P31 & P31R & P31S & P31T \\
\hline P32 & P32R & P32S & P32T \\
\hline P33 & P33R & P33S & P33T \\
\hline
\end{tabular}

Tabel 5 di atas berisi daftar kode variabel dan kode kelas dari rentang dari rendah ke tinggi berdasarkan tingkat keparahan gejala penyakit tanaman karet. Terdapat 33 jenis gejala penyakit tanaman karet, yangetiap jenis gejala mempunyai tingkat keparahan rendah, sedang dan tinggi dengan label yang disediakan pada tabel 2 kolom himpunan.

Tabel 6.. Daftar Penyakit Pada Tanaman Karet.

$\begin{array}{rll}\text { NO } & \text { Nama Kelas Penyakit } & \text { Output } \\ 1 & \text { Penggerak Batang (Xyleborus sp) } & \text { O1 } \\ 2 & \text { Rayap (captotermes curvignatus) } & \text { O2 } \\ 3 & \text { Kutu Tempurung (Coccus sp). } & \text { O3 } \\ 4 & \text { Uret } & \text { O4 } \\ & \begin{array}{l}\text { Penyakit Nekrosis kulit/Bark Necrosis } \\ \text { (Fusarium sp) }\end{array} & \text { O5 } \\ & \begin{array}{l}\text { Penyakit Jamur Upas (corticium } \\ \text { salmonicolor) }\end{array} & \text { O6 } \\ & \text { Penyakit Kanker Garis (Phytophthora } & \text { O7 } \\ 7 & \text { palmivora) } & \\ & \text { Penyakit Mouldy Rot (ceratocytis } & \text { O8 } \\ 8 & \text { fimbriata) } & \text { O9 } \\ 9 & \text { Kering alur sadap } & \text { O10 } \\ 10 & \text { Jamur Akar Putih } & \text { O11 } \\ 11 & \text { Embun Tepung } & \text { O12 } \\ 12 & \text { Gugur daun } & \text { O13 } \\ 13 & \text { Jamur Corynespora cassiicola } & \text { O14 } \\ 14 & \text { Penyakit daun Helminthosporium sp. } & \end{array}$

Pada tabel 6 ditampilkan daftar penyakit pada tanaman karet. Terdapat 14 diagnosis penyakit yang diputuskan berdasarkan 33 gejala penyakit tanaman karet yang telah didefenisikan pada tabel sebelumnya.

Tabel 7. Daftar Rule yang dibangun berdasarkan Keilmuan Diagnosis Penyakit Tanaman Karet.

\begin{tabular}{|c|c|c|c|c|c|c|c|}
\hline $\begin{array}{c}\text { Atura } \\
\mathbf{n}\end{array}$ & P1 & P2 & P3 & P4 & P5 & P6 & $\begin{array}{c}\text { Hasi } \\
\text { I }\end{array}$ \\
\hline $\mathrm{A} 1$ & P1T & P2T & P3T & P4T & P5T & P6T & $\mathrm{O} 2$ \\
\hline A2 & P1T & P2T & P3T & P4T & P5T & P6S & $\mathrm{O} 3$ \\
\hline A3 & P1T & P2T & P3T & P4T & P5T & P6R & $\mathrm{O} 4$ \\
\hline A4 & P1T & P2T & P3T & $\mathrm{P} 4 \mathrm{~T}$ & P5S & P6T & O5 \\
\hline A5 & P1T & P2T & P3T & P4T & P5S & P6S & O6 \\
\hline A6 & P1T & P2T & P3T & P4T & P5S & P6R & O1 \\
\hline A7 & P1T & P2T & P3T & P4T & P5R & P6T & $\mathrm{O} 2$ \\
\hline A8 & P1T & P2T & P3T & P4T & P5R & P6S & $\mathrm{O} 3$ \\
\hline A9 & P1T & P2T & P3T & P4T & P5R & P6R & $\mathrm{O} 4$ \\
\hline A10 & P1T & P2T & P3T & P4T & P5T & P6T & O5 \\
\hline A11 & P1T & P2T & P3T & P4T & P5T & P6S & $\mathrm{O} 2$ \\
\hline A12 & P1T & P2T & P3T & P4T & P5T & P6R & $\mathrm{O} 3$ \\
\hline A13 & P1T & P2T & P3T & P4T & P5S & P6T & $\mathrm{O} 4$ \\
\hline A14 & P1T & P2T & P3T & P4T & P5S & P6S & O5 \\
\hline \multirow[t]{2}{*}{ A15 } & P1T & P2T & P3T & $\mathrm{P} 4 \mathrm{~T}$ & P5S & P6R & O6 \\
\hline & $\ldots \ldots$ & $\ldots \ldots$ & ...... & $\ldots \ldots$ & $\ldots \ldots$ & $\ldots \ldots$ & \\
\hline A729 & P1R & P2R & P3R & P4R & P5R & P6R & O14 \\
\hline
\end{tabular}

Tabel 7 di atas berisi daftar rule yang dibangun berdasarkan keilmuan diagnosis penyakit tanaman karet. Aturan atau rule diagnosis penyakit terdaftar dengan kode A (aturan). Terdapat $33^{\wedge} 3$ aturan yang terdefenisi. Aturan atau rule tersebutlah yang digunakan untuk mendiagnosis penyakit pada tanaman karet. Perlu daftar list data gejala pada suatu tanaman karet untuk mencocokan gejala dengan rule diagnosis peyakit tanaman karet.

Tabel 8. Nilai Kecenderungan Rule Terhdapa Diagnosis

\begin{tabular}{lllr}
\multicolumn{4}{c}{ Penyakit Karet. } \\
\hline Rule & Variabel & Diagnosis & Nilai Kecenderungan \\
\hline R1 & P28 & O1 & 0.8 \\
R2 & P8 & O1 & 0.2 \\
R3 & P19 & O2 & 0.5 \\
R4 & P29 & O2 & 0.9 \\
R5 & P30 & O3 & 0.8 \\
R6 & P31 & O4 & 0.5 \\
R7 & P32 & O3 & 0.8 \\
R8 & P8 & O3 & 0.2 \\
R9 & P8 & O4 & 0.2 \\
R10 & P11 & O4 & 0.5 \\
R11 & P33 & O4 & 0.9 \\
R12 & P1 & O5 & 0.7 \\
R13 & P2 & O5 & 0.7 \\
R14 & P3 & O5 & 0.5 \\
R15 & P4 & O5 & 0.8 \\
R16 & P5 & O6 & 0.7 \\
R17 & P6 & O6 & 0.2 \\
R18 & P7 & O6 & 0.5 \\
R19 & P8 & O6 & 0.2 \\
R20 & P9 & O7 & 0.5 \\
R21 & P6 & O7 & 0.2 \\
R22 & P8 & O7 & 0.2 \\
R23 & P10 & O8 & 0.6 \\
R24 & P11 & O8 & 0.5 \\
R25 & P12 & O8 & 0.6 \\
R26 & P8 & O8 & 0.2 \\
R27 & P6 & O9 & 0.2 \\
R28 & P7 & O9 & 0.5 \\
R29 & P8 & O9 & 0.2
\end{tabular}




\begin{tabular}{llll} 
R30 & P15 & O10 & 0.6 \\
R31 & P16 & O10 & 0.6 \\
R32 & P14 & O10 & 0.8 \\
R33 & P13 & O10 & 0.5 \\
R34 & P17 & O11 & 0.8 \\
R35 & P18 & O11 & 0.7 \\
R36 & P22 & O11 & 0.5 \\
R37 & P13 & O12 & 0.5 \\
R38 & P22 & O12 & 0.5 \\
R39 & P20 & O12 & 0.6 \\
R40 & P13 & O13 & 0.5 \\
R41 & P22 & O13 & 0.5 \\
R42 & P23 & O13 & 0.6 \\
R43 & P24 & O14 & 0.8 \\
R44 & P26 & O14 & 0.5 \\
R45 & P27 & O14 & 0.5 \\
R46 & P25 & O14 & 0.7 \\
\hline
\end{tabular}

Tabel 8 di atas berisi daftar nilai kecenderungan rule terhdapa diagnosis penyakit karet. Tidak semua rule atau aturan pasti bernilai mutlak terhadap suatu diagnosis.

Tabel di atas adalah hasil perhitungan kecenderungan sebuah aturan dengan gejala tertentu terhadap suatu diagnosis. Dapat dilihat bahwa, beberapa hasil diagnosis penyakit dapat mempunyai aturan yang sama dengan beberapa gejala berdekatan.

Tabel 9. Hasil Pengujian Algoritma Fuzzy Mamdany pada Diagnosis Penyakit Karet

\begin{tabular}{ccc}
\hline Data Training & \multicolumn{2}{c}{131 instance dengan label } \\
\hline Data Uji & \multicolumn{2}{c}{ 60 instance tanpa label } \\
\hline Akurasi & 5-Cross Validation & 10-Cross validation \\
$81.28 \%$ & $80.47 \%$ & $81.84 \%$ \\
\hline
\end{tabular}

\section{KESIMPULAN}

Dari hasil perhitungan yang dilakukan dalam mendiagnosis penyakit tanaman karet sebanyak 161 data objek tanaman karet yang dilengkapi dengan identitas 33 gejala serta diagnosis dari data perkebunan, kemudian diujikan 60 data tanaman karet yang tidak ada label diagnosis, kami memperoleh nilai akurasi sebesar $81.28 \%$. Begitu juga pengujian dengan pengacakan data training dengan Cross Validation diperoleh hasil yang berdekatan.

\section{REFERENSI}

Fajri, R. I. (2014). Identifikasi Penyakit Daun Tanaman Kelapa Sawit Menggunakan Support Vector Machine. Jurnal Teknologi Perkebunan. Retrieved from http://repository.usu.ac.id/handle/123456789/4 2256

Filie, \& Kusuma, M. (2011). Sistem Pakar Untuk Mendiagnosa Penyakit Pada Tanaman Karet Dan Cara Penanggulangannya.

Hayadi, B. H., \& Setiawan, A. (2016). Sistem Berbasis Pengetahuan Dengan Menggunakan Fuzzy Tsukamoto (Untuk Kesehatan Dan
Perawatan Bayi). Seminar Nasional Teknologi Informasi Dan Komunikasi 2016, 2016(Sentika), 18-19.

Kamsyakawuni, A., Gernowo, R., \& Sarwoko, E. A. (2012). Aplikasi Sistem Pakar untuk Diagnosa Penyakit Hipertiroid dengan Metode Inferensi Fuzzy Mamdani. Jurnal Sistem Informasi Bisnis, 2(2), 58-66. https://doi.org/10.21456/vol2iss2pp058-066

Kaur, A., \& Kaur, A. (2012). Comparison of Mamdani-Type and Sugeno-Type Fuzzy Inference Systems for Air Conditioning System. International Journal of Soft Computing \& Engineering, 2(2), 323-325. Retrieved from http://citeseerx.ist.psu.edu/viewdoc/download? doi=10.1.1.486.1238\&rep=rep1\&type $=$ pdf

Mahua, M. S. (2018). SISTEM PAKAR UNTUK MENDIAGNOSIS PENYAKIT TANAMAN JERUK ( LIMAU ) MENGGUNAKAN METODE BAYES. JATI (Jurnal Mahasiswa Teknik Informatika), 2(2), 196-202.

Maulana, Rizky, J., Fitriyadi, \& Fitriani, R. (2017). Sistem Pakar Diagnosa Penyakit Tanaman Karet. JUTISI, 1(3), 67-70.

Mustaqim, K. (2013). Aplikasi Sistem Pakar Untuk Diagnosa Hama dan Penyakit Tanaman Kelapa Sawit Menggunakan Naive Bayes( STUDY KASUS : PT . Perkebunan Nusantara $V)$.

Nurhatika, S. (2013). Sistem Pakar Untuk Mendiagnosis Penyakit Tanaman Kelapa Sawit.

Sidauruk, A., \& Pujianto, A. (2017). Sistem Pakar Diagnosa Penyakit Tanaman Kelapa Sawit menggunakan Teorema Bayes. Jurnal Ilmiah Data Manajemen Dan Teknologi Informasi, 18(maret).

Sumitre, M., Kurniawan, R., Informatika, J., \& Alam, J. Z. A. P. (2014). Rancang Bangun Sistem Pendukung Keputusan Seleksi Penerimaan Tenaga Pengajar Dengan Metode Fuzzy Inference System (Fis) Mamdani. Jurnal Informatika Darmajaya, 14(1), 61-71. https://doi.org/10.30873/ji.v14i1.512

\section{PROFIL PENULIS}

Hendrawan merupakan dosen yang aktif mengajar dan penelitian serta pengabdian di Universitas Dinamika Bangsa (UNAMA) Jambi. Bidang penelitian yang didalami antara lain adalah sistem informasi. Saat ini, menjabat sebagai Wakil Rektor II bidang keuangan di UNAMA.

Abdul Haris merupakan dosen yang aktif mengajar dan penelitian serta pengabdian di Universitas Dinamika Bangsa (UNAMA) Jambi. Bidang penelitian yang didalami antara lain adalah sistem informasi dan perangkat lunak. Saat ini, menjabat sebagai 
Paradigma - Jurnal Informatika dan Komputer,

Vol. 22, No. 2 September 2020

P-ISSN 1410-5063, E-ISSN: 2579-3500

$\begin{array}{llr}\text { sekretaris } & \text { Lembaga Penelitian } & \text { dan } \\ \text { Pengabdian } & \text { Masyarakat } & \text { (LPPM) }\end{array}$ UNAMA.

Errissya Rasywir merupakan dosen yang aktif mengajar dan penelitian serta pengabdian di Universitas Dinamika Bangsa (UNAMA) Jambi. Bidang penelitian yang didalami antara lain adalah kecerdasan buatan, pengolahan citra serta pengolahan teks. Menamatkan pendidikan S1 di Universitas Sriwijaya dan pendidikan S2 di Institut Teknologi Bandung. Selain itu, saat ini, juga menjabat Ketua Lembaga Penjaminan Mutu Pendidikan (LPMP) di UNAMA.
Yovi Pratama merupakan dosen yang aktif mengajar dan penelitian serta pengabdian di Universitas Dinamika Bangsa (UNAMA) Jambi. Bidang penelitian yang didalami antara lain adalah kecerdasan buatan, pengolahan citra serta pengolahan teks. Selain aktif menjadi dosen, juga berperan aktif sebagai developer perangkat lunak. Terdapat banyak perangkat lunak yang telah dibangun untuk kepentingan pihak swasta maupun pemerintah di Kota Jambi. 